\title{
ANTIMICROBIAL PEPTIDE MPX ALLEVIATES THE LETHAL ATTACK OF ESCHERICHIA COLI IN MICE
}

\author{
Xueqin Zhao \\ Postgraduate student \\ Sumy National Agrarian University of Ukraine, Sumy, Ukraine, \\ College of Animal Science and Veterinary Medicine of Henan Institute of Science and Technology, Xinxiang, China \\ ORCID: 0000-0002-4713-4685 \\ zxueqin0708@163.com
}

Fotina Hanna

Doctor of Veterinary Sciences, Professor Sumy National Agrarian University, Sumy, Ukraine ORCID: 0000-0002-0761-3681

hanna.fotina@snau.edu.ua

\begin{abstract}
Lei Wang
College of Animal Science and Veterinary Medicine of Henan Institute of Science and Technology, Xinxiang China ORCID: 0000-0001-7972-7680 wlei_007@163.com

Jianhe Hu

College of Animal Science and Veterinary Medicine of Henan Institute of Science and Technology, Xinxiang, China ORCID: 0000-0002-5248-0312 jianhehu@126.com
\end{abstract}

Escherichia coli is an important zoonotic pathogen causing intestinal diseases. In recent years, due to the unreasonable use of antibiotics, the drug resistance of bacteria has been increasing, and the proportion of multi-drug resistant strains has also been rising, which directly threatens the health of animals and humans. $80 \%$ of E. coli are multi-drug resistant strains, with strong resistance to aminoglycosides, sulfonamides, tetracyclines, and chloramphenicol. E. coli is extremely harmful and difficult to control. Therefore, there is an urgent need to find new antibacterial drugs that against $E$. coli infection and not easy to develop drug resistance. Antimicrobial peptides are a type of small molecule peptides that can resist the invasion of pathogenic microorganisms into the body. They are an important part of the innate immune system. With their small molecular weight, good water solubility, and resistance to resistance, they are considered the best alternative to antibiotics and become a research hotspot in recent years. The antimicrobial peptide MPX was isolated from wasp venom and had better antibacterial activity against both Gram-positive and Gram-negative bacteria. Studies have found that MPX had better bactericidal activity against $E$. coli in vitro. However, whether MPX also has better bactericidal activity in mice still unknown. In this study, the results found that $E$. coli infected mice loss of appetite, diarrhea, and grouping together, while $M P X$ treatment significantly alleviated these symptoms. The results of autopsy found that the intestinal congestion, bleeding, thinning of the intestinal wall, yellow viscous fluid in the intestinal cavity, congestion of the lungs, necrosis in the liver, congestion and bleeding of the spleen, and MPX treatment effectively relieved the above symptoms. The qRT-PCR results found that MPX could increase the MRNA expression of the antibacterial protein TFF3 in the jejunum and colon, and reduce the expression of the antibacterial protein Rem/ $\beta$ and REG3y in the jejunum and colon. H\&E staining results further found that MPX could alleviate the pathological damage of mouse intestines and organs caused by $E$. coli infection. The above results show that MPX has good bactericidal activity against $E$. coli infection in mice, providing an important reference for the screening of drugs for the clinical treatment of $E$. coli infection.

Key words: antimicrobial peptide MPX, Escherichia coli, mice.

DOI https://doi.org/10.32845/bsnau.vet.2021.3.8

Introduction. Escherichia coli is gram-negative bacterium and common zoonotic pathogen, which causes many human epidemics. In the United States, more than 100,000 people were infected with EHEC 0157:H7 every year (M, et al., 2019). Studies have reported that the infection of EHEC in pig intestinal tract contents and feces in central of China is high (YM, et al., 2021). The harm of $E$. coli is not only manifested in causing animal diseases and bringing huge economic losses to the breeding industry and animal husbandry, but also a reservoir of drug resistance genes for other pathogenic bacteria, and the drug resistance genes carried by food chain passed to Humans (G, et al., 2021). $80 \%$ of $E$. coli are multi-drug resistant strains, with strong resistance to aminoglycosides, sulfonamides, tetracyclines, and chloramphenicol (S, 2021). E. coli is extremely harmful and difficult to control. Therefore, there is an urgent need to find new antibacterial drugs that against $E$. coli infection and not easy to develop drug resistance.

Antimicrobial peptides are a type of small molecule peptides that can resist the invasion of pathogenic microorganisms into the body. They are an important part of the innate immune system. With their small molecular 
weight, good water solubility, and resistance to resistance, they are considered the best alternative to antibiotics and become a research hotspot in recent years (Santos, et al., 2021). Antimicrobial peptides have various biological functions such as anti-bacterial, anti-virus, anti-parasitic, antiinflammatory, anti-cancer, improving animal performance and immunity (Al, et al., 2021; Piyadasa, et al., 2021; Xie, et al., 2020; Gong, et al., 2021). MPX was extracted from wasp venom consisted of 14 amino acids and had 4 positive charges which had good bactericidal activity against both Gram-positive and Gram-negative bacteria (X, et al., 2021). Previous studies of our group found that MPX had good bactericidal activity against $E$. coli in vitro. Whether MPX also had good bactericidal activity in vivo still unknown.

Aim. The purpose of this study is to further explore the effect of MPX against $E$. coli infection in vivo.

\section{Materials and methods.}

Ethics Statement. BALB/c mice (18-22 g, female) were purchased from Zhengzhou University (Henan Province, China). All animal experiments were approved by the Animal Ethics Committee and were performed in accordance with the guidelines of the Animal Welfare and Research Ethics Committee.

Peptide Synthesis. Antimicrobial peptide MPX (H-INWKGIAAMAKKLL-NH2) was synthesized and purified by Ji er sheng hua (Shanghai, China) at purity greater than $98 \%$ and antimicrobial peptide MPX was very soluble in $\mathrm{ddH}_{2} \mathrm{O}$.

Clinical symptoms and observation of necropsy lesions. BALB/C mice were randomly divided into 4 groups, namely control group, E. coli, E. coli + MPX, $E$. coli + enrofloxacin, and the dose of $E$. coli infected BALB/C mice was $4.5 \times 10^{7} \mathrm{CFU} / \mathrm{mice}$, MPX (20 mg/kg) and Enro $(20 \mathrm{mg} / \mathrm{kg}$ ) were treated by intraperitoneal injection after infection with $E$. coli for $2 \mathrm{~h}$, and treatment was continued for 3 days. Observed the clinical manifestations and necropsy of the mice after $E$. coli infection, took out the mouse lungs, liver, spleen and intestines with scissors and toothless forceps, observed the pathological changes of the mouse intestines and organs, and took pictures.

qRT-PCR. Total RNA extraction kit (Solarbio, China) was used to extract total RNA from mouse jejunum and colon. Jejunum and colon powder was slowly added to $1.5 \mathrm{~mL} E P$, $200 \mu \mathrm{L}$ chloroform was added to each well, and shaken on a shaker for $15 \mathrm{~s}$, centrifuged at $12000 \mathrm{rpm}, 4^{\circ} \mathrm{C}$ for $10 \mathrm{~min}$, added $500 \mu \mathrm{L}$ isopropanol and mix well, centrifuged at 12000 rpm, $4^{\circ} \mathrm{C}$ for $10 \mathrm{~min}$, discard the supernatant, added $1 \mathrm{~mL}$ to each tube 75 centrifuge in $\%$ ethanol, $12000 \mathrm{rpm}, 4^{\circ} \mathrm{C}$ for 5 min, added 20-30 $\mu \mathrm{L}$ of DEPC water and mix well, then measure the RNA concentration. Reverse transcription kit (Takala, Japan) was used to reverse RNA into cDNA. The primer sequences as shown in Table 1.

H\&E staining. After wiping clean with alcohol cotton, the mouse organs and intestines were fixed with $4 \%$ paraformaldehyde, paraffin embedded, sectioned, and H\&E stained to observe the pathology of the mouse duodenum, ileum, colon and liver, spleen, and lungs. Change, refer to the specific operation steps (He, et al., 2015).

Statistical Analysis. GraphPad Prism 5 data processing software to carry out and difference analysis of experimental results (One-Way ANOVA), $\mathrm{P}<0.05$ means significant difference (marked in the text ${ }^{*} \mathrm{P}<0.05$; ${ }^{*} \mathrm{P}<0.01$; *** $P<0.001 ; \# P<0.05$; \#P $<0.01$; \#\#P $<0.001$ )

Results and discussion.

MPX alleviates the clinical manifestations of mice. Observation of clinical symptoms after infection of $E$. coli in mice was shown in Figure $1 \mathrm{~A}$ and $\mathrm{B}$ : mice infected with E. coli alone showed loss of appetite, rapid heartbeat, body tremor, loose hair, bunching up, arched back, anal prolapse, feces clinical manifestations such as irregularities, while MPX treatment significantly alleviated the adverse reactions caused by $E$. coli infection. Mice increased appetite, smooth coat, and the effect was better than enrofloxacin treatment. The control group did not show any adverse reactions.

Table 1

The primer sequences for qRT-PCR

\begin{tabular}{cl}
\hline \multicolumn{1}{c}{ Genes } & \multicolumn{1}{c}{ Sequence } \\
\hline \multirow{2}{*}{ Reg3y } & F:5'-CCCGACACTGGGCTATGAAC-3' \\
& R:5'-GGTACCACAGTGATTGCCTGA-3' \\
Relm $\beta$ & F:5'-CTGATAGTCCCAGGGAACGC-3' \\
& R:5'-GTCTGCCAGAAGACGTGACA-3' \\
TFF3 & F:5' -CCTGGTTGCTGGGTCCTCTG-3' \\
& R:5'-GCCACGGTTGTTACACTGCTC-3' \\
GAPDH & F:5' -GAGAAACCTGCCAAGTATGATGAC-3' \\
& R:5'-TAGCCGTATTCATTGTCATACCAG-3'
\end{tabular}

Figure 1. Observation of clinical symptoms of $E$. coli infection with BALB/c mice (A, B)

MPX alleviates the pathological changes of mice by necropsy. The results of the necropsy were shown in Figure 2, the intestines of mice in the control group were normal, with thick and flexible intestinal walls, and no pathological changes were seen in the liver, spleen, and lungs. Mice infected with $E$. coli had intestinal congestion, hemorrhage, intestinal wall thinning and easy to rupture, the intestinal cavity was filled with yellow viscous liquid, the jejunum was severely congested, and the lungs, liver, and spleen were congested and bleeding. While MPX could effectively alleviate the intestinal inflammatory response and organ pathological damage caused by $E$. coli infection, and its effect was equivalent to that of the antibiotic Enro.

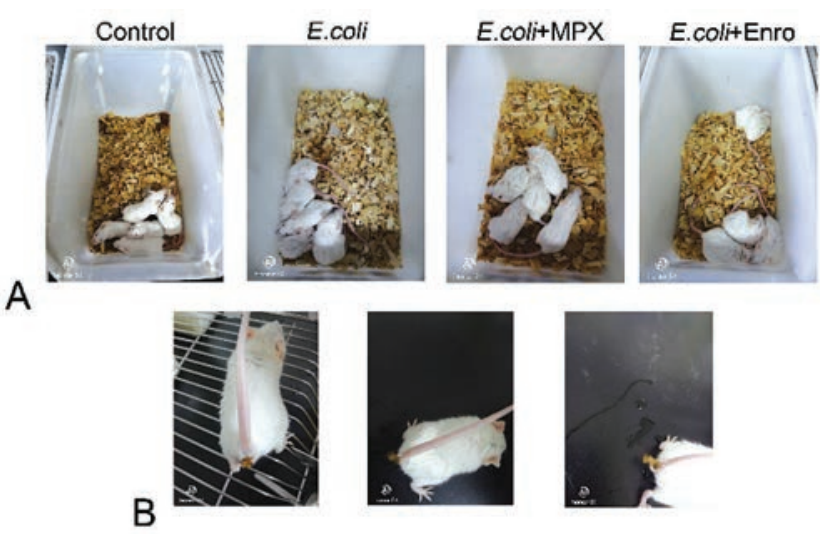

Figure 2. Autopsy results of mouse intestines and organs after $E$. coli infection 
MPX increases the expression of intestinal antimicrobial peptide protein. The mRNA expression of intestinal antibacterial related proteins REG3y, RemI $\beta$, and TFF3 by qRT-PCR. In the jejunum (Figure 3A), compared with the control group, the TFF3 gene expression level in the jejunum of the $E$. coli group was increased $(P<0.05)$; while the TFF3 gene expression in the jejunum of $E$. coli+MPX significantly lower than the $E$. coli group $(P<0.05)$, and no significant difference from the control group. Compared with the control group, the mRNA expression level of Remlßin the jejunum tissue of $E$. coli infected mice was significantly increased $(P<0.001)$. MPX significantly reduced the mRNA expression level of Reml $\beta$, which was equivalent to the effect of Enro; while the expression level of RemIßin mouse colon was not significantly different in other group. In addition, $E$. coli infection leads to increased REG3y expression in mouse jejunum and colon, and MPX could significantly reduce REG3y mRNA expression caused by $E$. coli infection.

$A$ : The mRNA expression of TFF3 in mouse jejunum and colon; B: The mRNA expression of Reml $\beta$ in mouse jejunum and colon; $\mathrm{C}$ : The mRNA expression of REG3y in mouse jejunum and colon.
MPX relieves intestine pathological damage. Further H\&E staining was used to observe the pathological changes of the duodenum, ileum and colon after $E$. coli infection. As shown in Figure 4, the duodenum, ileum, and colon of mice infected with $E$. coli showed intestinal villi shedding, breaking and falling into the intestinal lumen, catarrhal enteritis, degeneration, necrosis, shedding of intestinal mucosal epithelial cells, congestion of the lamina propria and a large number of neutrophil infiltration, showing the pathology of necrotizing enteritis and fibrinous necrotizing enteritis Changes (Figure 4A, B, C). While the pathological changes of each bowel segment were significantly alleviated after treatment with MPX. The intestinal villi of the control were neatly arranged without the above-mentioned pathological changes.

MPX relieves pathological damage of organs in mice. E. coli-infected mice developed acute interstitial pneumonia, widened alveolar septum, ruptured alveoli, neutrophil infiltration, and mild lung disease, showing local pulmonary congestion and a small amount of red blood cell and inflammatory cell infiltration (Figure 5A). Symptoms of hemorrhagic splenitis, congestion, local necrosis, small
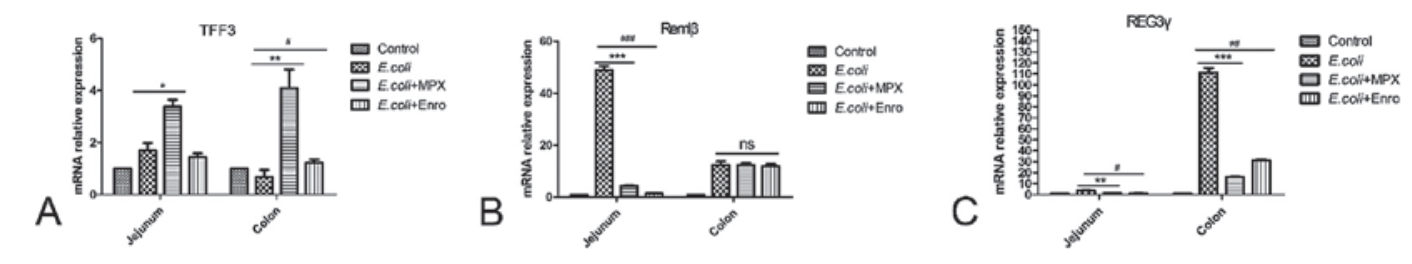

Figure 3. Them RNA expression of antibacterial protein in mouse intestine
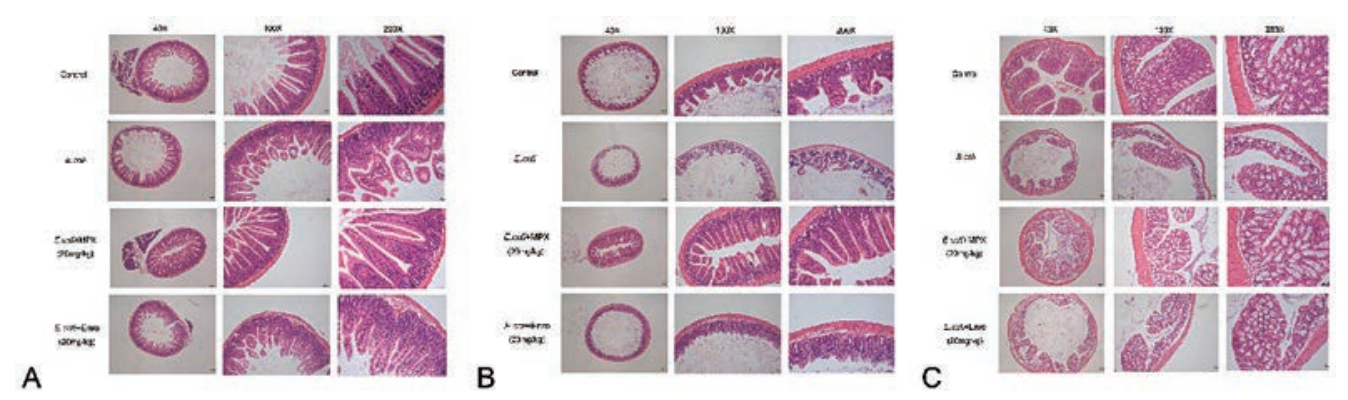

Figure 4. H\&E staining of intestines after $E$. coli infection in mice. A: H\&E staining of duodenum after $E$. coli infection in mice; B: H\&E staining of ileum after $E$. coli infection in mice; C: H\&E staining of colon after $E$. coli infection in mice
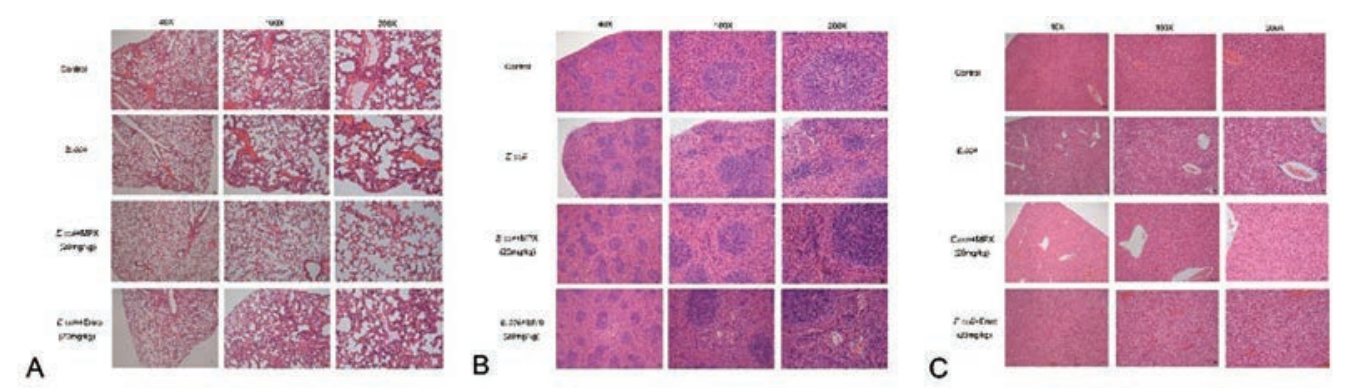

Figure 5. H\&E staining of the organs infected with E. coli in mice. A: H\&E staining of lung infected with $E$. coli in mice; B: H\&E staining of spleen infected with $E$. coli in mice; C: H\&E staining of liver infected with $E$. coli in mice 
splenic corpuscles appear in the spleen, a large number of neutrophil infiltration in the splenic sinus (Figure 5B), degeneration and necrosis of hepatocytes, and acute necrosis in the liver, disintegration of liver cells, congestion, liver congestion, dilation of liver sinusoids, infiltration of red blood cells and neutrophils (Figure 5C). The above symptoms were significantly alleviated after treatment with MPX, indicating that MPX can protect mice against the damage of $E$. coli to the organs.

Discussion. In this study, E. coli was used to establish $B A L B / C$ mouse infection model, and MPX treatment to evaluate the effect against $E$. coli infection in mice. The clinical symptoms, intestinal and organ necropsy and pathological changes, and the mRNA expression of antibacterial protein in mice were evaluated. The results showed that MPX could alleviate the clinical symptoms of mice caused by $E$. coli infection, relieve the pathological changes of the intestines and organs, and increase the mRNA expression of the antimicrobial protein TFF3. This study evaluated the effect of MPX against $E$. coli in vivo, laying a foundation for the study of MPX in mice, providing a reference of drugs for the treatment of $E$. coli infection.

MPX can alleviate the intestinal damage caused by $E$. coli infection in mice. Intestine is the largest digestion and absorption organ of animal, as well as the most important immune organ of the body. Zhang et al. found that adding antimicrobial peptide plectas in to chicken diets could improve chicken performance, immune function and intestinal health, and increase the length of intestinal villi (Zhang, et al., 2021). Roque-Borda CA et al. found that the antimicrobial peptide Ctx(Ile)-Ha could effectively alleviate intestinal pathological damage (Roque-Borda, et al., 2021). Shang et al. found that the antimicrobial peptide Microcin J25 could alleviate DSS-induced intestinal inflammation and improve intestinal morphology (Shang, et al., 2021). Xiong et al. found that oral antimicrobial peptide-defensin-1 (DEFB1) could improve intestinal function and enhance intestinal barrier function (Xiong, et al., 2021). The results found that MPX could effectively reduce the intestinal damage caused by $E$. coli infection in mice.

Intestine is in direct contact with the external environment and colonizes a large number of microorganisms. Antimicrobial proteins secreted by intestinal epithelial cells play an important role in maintaining the homeostasis of intestinal epithelium and normal microbial flora (Gallo, et al., 2012; Wlodarska, et al., 2010). REG3y is mainly expressed in the small intestine tissues of mice and humans. In addition, REG3y also conditionally expressed when pathogen infection or inflammation occurs in the large intestine tissues (Christa, et al., 1996). Study showed that REG3y was almost not expressed in the intestinal tract of sterile mice, and the expression of REG3y was significantly increased after the normal flora was colonized (Cash, et al., 2006). The expression of RemLp is mainly regulated by Th2 cytokines, which plays an important role in the process of innate immunity and host defense (A, et al., 2017). TFF3 is produced by mucous secreting cells, which plays an important role in the function of the intestinal mucus layer and mucosal repair function (Ge, et al., 2015). In this study, the results found that MPX can increase the mRNA expression of the antimicrobial protein TFF3 in the jejunum and colon, and reduce the expression of the antimicrobial protein RemI $\beta$ and REG3y in the jejunum and colon.

In conclusion, MPX can resist the lethal attack of $E$. coli in mice, alleviate the pathological changes of mice intestines and organs, and increase or decrease the mRNA expression of antimicrobial proteins in the jejunum or colon to varying degrees, providing important reference value for clinical drug screening of $E$. coli infection.

Author's contributions. Xueqin Zhao participated in the study design, carried out data analyses, participated and performed measurements, laboratory testing's and wrote this manuscript.

Acknowledgements. This work was supported by the Young Talent Lifting Project in Henan Province (2020HYTP041); the Key scientific research projects of colleges and universities in Henan Province (21A230004); the National Key Research and Development Program of China (2019YFC605700); Open Project of State Key Laboratory of Marine Resources Utilization in South China Sea (Hainan University, MRUKF2021004 $\square$ the Youth Backbone Teacher Project of Colleges and Universities of Henan Province (2020GGJS162); the Innovative Research Team (in Science and Technology) in University of Henan Province (20IRTSTHN025); Climbing Project of Henan Institute of Science and Technology (2018JY02).

1. Conflict of interest. Author does not report any financial or personal connections with other persons or organizations, which might negatively affect the contents of this publication and/or claim authorship rights to this publication.

\section{References:}

1. A, H., A, T., \& H, N. (2017). Localization of RELM- $\beta / F I Z Z 2$ Is Associated with Cementum Formation. Anatomical record (Hoboken, N.J.: 2007), 300(10), 1865-1874. DOI: 10.1002/ar.23636.

2. Al, A.S., Padhi, A., Karadottir, H., Morman, C., Graslund, A., Vegvari, A., Johansson, J., Rising, A., Agerberth, B., \& Bergman, P. (2021). Citrullination Alters the Antibacterial and Anti-Inflammatory Functions of the Host Defense Peptide Canine Cathelicidin K9CATH In Vitro. J Immunol, 207(3), 974-984. DOI: 10.4049/jimmunol.2001374.

3. Cash, H.L., Whitham, C.V., Behrendt, C.L., \& Hooper, L.V. (2006). Symbiotic bacteria direct expression of an intestinal bactericidal lectin. Science, 313(5790), 1126-30. DOI: 10.1126/science.1127119.

4. Christa, L., Carnot, F., Simon, M.T., Levavasseur, F., Stinnakre, M.G., Lasserre, C., Thepot, D., Clement, B., Devinoy, E., \& Brechot, C. (1996). HIP/PAP is an adhesive protein expressed in hepatocarcinoma, normal Paneth, and pancreatic cells. Am J Physiol, 271(6 Pt 1), G993-1002. DOI: 10.1152/ajpgi.1996.271.6.G993.

5. G, L., Y, R., S, W., X, C., H, X., \& Y, S. (2021). Escherichia coliCo-Occurrence of NDM-9 and MCR-1 in a Human Gut Colonized ST1011. Infection and drug resistance, 14(3011-3017). DOI: 10.2147/IDR.S321732. 
6. Gallo, R L., \& Hooper, L.V. (2012). Epithelial antimicrobial defence of the skin and intestine. Nat Rev Immunol, 12(7), 503-516. DOI: 10.1038/nri3228.

7. Ge, H., Gardner, J., Wu, X., Rulifson, I., Wang, J., Xiong, Y., Ye, J., Belouski, E., Cao, P., Tang, J., Lee, K.J., Coberly, S., Wu, X., Gupte, J., Miao, L., Yang, L., Nguyen, N., Shan, B., Yeh, W C., Veniant, M.M., Li, Y., \& Baribault, H. (2015). Trefoil Factor 3 (TFF3) Is Regulated by Food Intake, Improves Glucose Tolerance and Induces Mucinous Metaplasia. PLoS One, 10(6), e0126924. DOI: 10.1371/journal.pone.0126924.

8. Gong, C., Sun, J., Xiao, Y., Qu, X., \& Lang, M. (2021). Synthetic Mimics of Antimicrobial Peptides for the Targeted Therapy of Multidrug-Resistant Bacterial Infection. Adv Healthc Mater, e2101244. DOI: 10.1002/adhm.202101244.

9. He, Q., Li, J.K., Li, F., Li, R.G., Zhan, G.Q., Li, G., Du WX, \& Tan, H.B. (2015). Mechanism of action of gypenosides on type 2 diabetes and non-alcoholic fatty liver disease in rats. World J Gastroenterol, 21(7), 2058-66. DOI: 10.3748/wjg.v21. i7.2058.

10. M, M., A, B., R, G., F, O., E, P., M, C., F, L., S, C., D, B., K, B., \& M, P. (2019). Recovery from mild Escherichia coli 0157:H7 infection in young and aged C57BL/6 mice with intact flora estimated by fecal shedding, locomotor activity and grip strength. Comparative immunology, microbiology and infectious diseases, 63(1-9). DOI: 10.1016/j.cimid.2018.12.003.

11. Piyadasa, H., Hemshekhar, M., Osawa, N., Lloyd, D., Altieri, A., Basu, S., Krokhin, O.V., Halayko, A.J., \& Mookherjee, N. (2021). Disrupting Tryptophan in the Central Hydrophobic Region Selectively Mitigates Immunomodulatory Activities of the Innate Defence Regulator Peptide IDR-1002. J Med Chem, 64(10), 6696-6705. DOI: 10.1021/acs.jmedchem.0c02065.

12. Roque-Borda, C.A., Pereira, L.P., Guastalli, E., Soares, N.M., Mac-Lean, P., Salgado, D.D., Meneguin, A.B., Chorilli, M., \& Vicente, E.F. (2021). HPMCP-Coated Microcapsules Containing the Ctx(lle(21))-Ha Antimicrobial Peptide Reduce the Mortality Rate Caused by Resistant Salmonella Enteritidis in Laying Hens. Antibiotics (Basel), 10(6), DOI: 10.3390/antibiotics10060616.

13. S, B. (2021). Has resistance to chlorhexidine increased among clinically-relevant bacteria? A systematic review of time course and subpopulation data. PloS one, 16(8), e0256336. DOI: 10.1371/journal.pone.0256336.

14. Santos, B., Alves, E., Ferreira, C.S., Ferreira-Silva, A., Goes-Neto, A., Verly, R.M., Liao, L.M., Oliveira, S.C., \& de Magalhaes, M. (2021). Schistocins: Novel antimicrobial peptides encrypted in the Schistosoma mansoni Kunitz Inhibitor SmKI-1. Biochim Biophys Acta Gen Subj, 1865(11), 129989. DOI: 10.1016/j.bbagen.2021.129989.

15. Shang, L., Yu, H., Liu, H., Chen, M., Zeng, X., \& Qiao, S. (2021). Recombinant antimicrobial peptide microcin J25 alleviates DSS-induced colitis via regulating intestinal barrier function and modifying gut microbiota. Biomed Pharmacother, 139(111127). DOI: 10.1016/j.biopha.2020.111127.

16. Wlodarska, M., \& Finlay, B.B. (2010). Host immune response to antibiotic perturbation of the microbiota. Mucosal Immunol, 3(2), 100-3. DOI: 10.1038/mi.2009.135.

17. X, Z., L, W., C, Z., X, X., S, Z., Y, W., H, Z., Y, X., S, C., J, J., S, L., Y, W., X, W., G, Z., Y, B., H, F., \& J, H. (2021). Escherichia coli The Antimicrobial Peptide Mastoparan X Protects Against Enterohemorrhagic O157:H7 Infection, Inhibits Inflammation, and Enhances the Intestinal Epithelial Barrier. Frontiers in microbiology, 12(644887). DOI: 10.3389/ fmicb.2021.644887.

18. Xie, Z., Zhao, Q., Wang, H., Wen, L., Li, W., Zhang, X., Lin, W., Li, H., Xie, Q., \& Wang, Y. (2020). Effects of antibacterial peptide combinations on growth performance, intestinal health, and immune function of broiler chickens. Poult Sci, 99(12), 6481-6492. DOI: 10.1016/j.psj.2020.08.068.

19. Xiong, B., Zhang, W., Wu, Z., Liu, R., Yang, C., Hui, A., Huang, X., \& Xian, Z. (2021). Okra pectin relieves inflammatory response and protects damaged intestinal barrier in caerulein-induced acute pancreatic model. J Sci Food Agric, 101(3), 863-870. DOI: 10.1002/jsfa.10693.

20. YM, B., H, S., \& SY, L. (2021). Salt, glucose, glycine, and sucrose protect Escherichia coli O157:H7 against acid treatment in laboratory media. Food microbiology, 100(103854). DOI: 10.1016/j.fm.2021.103854.

21. Zhang, X., Zhao, Q., Wen, L., Wu, C., Yao, Z., Yan, Z., Li, R., Chen, L., Chen, F., Xie, Z., Chen, F., \& Xie, Q. (2021). The Effect of the Antimicrobial Peptide Plectasin on the Growth Performance, Intestinal Health, and Immune Function of Yellow-Feathered Chickens. Front Vet Sci, 8(688611). DOI: 10.3389/fvets.2021.688611.

Ксюєцінь Дзяо, аспірант, Сумський національний аграрний університет, м. Суми, Україна

Фотіна Ганна, доктор ветеринарних наук, Сумський національний аграрний університет, м. Суми, Україна

Лей Ванг, коледж наук про тварин і ветеринарної медицини Інституту науки і техніки Хенань, Сіньсян, Китай

Ху Цзяньхе, профресор, коледж наук про тварин і ветеринарної медицини Інституту науки і техніки Хенань, Китай

Антимікробний пептид MPX зменшує летальний ефект Escherichia Coli у мишей

Кишкова паличка є важливим зоонозним збудником, що викликає кишкові захворювання. Останніми роками через необгрунтоване застосування антибіотиків зростає лікарська стійкість бактерій, а також зростає частка мультирезистентних итамів, що безпосередньо загрожує здоров'ю тварин і людини. 80\% штамів кишкової палички мають множинну лікарську стійкість до аміноглікозидів, сульфраніламідів, тетрациклінів та хлорамфеніколу. Кишкова паличка надзвичайно шкідлива, $і$ ії важко контролювати. Тому існує нагальна потреба у пошуку нових антибактеріальних препаратів, які ефрективні проти інфрекиії кишкової палички і до яких немає резистентності. Антимікробні пептиди - це тип пептидів, які можуть протистояти вторгненню патогенних мікроорганізмів в організм тварини і людини. Вони є важливою частиною вродженої імунної системи. Завдяки невеликій молекулярній масі, гарній розчинності у воді та стійкості до резистентності вони вважаються найкращою альтернативою антибіотикам, і останніми роками стали центром дослідження. Антимікробний пептид МРХ був виділений з отрути оси і мав кращу антибактеріальну активність як проти грампозитивних, так і грамнегативних бактерій. Дослідження показали, що MPX має кращу бактеріальну активність проти E. coli in vitro. Проте чи має MPX кращу бактерицидну 
активність у мишей, поки невідомо. У цьому дослідженні результати виявили, що кишкова паличка, що інффікувала мишей, викликала втрату апетиту, діарею та скупчення мишей разом, тоді як лікування МРХ значно полегшило ці симптоми. Результати розтину виявили кишкову непрохідність, кровотечу, зменшення стінки кишки, жовту в'язку рідину в кишковій порожнині, застійні явища в легенях, некроз у печіниі, застій і кровотечу селезінки. Застосування MPX ефрективно усуває вищевказані симптоми. Результати qRT-PCR виявили, що MPХ може підвищити експресію мPHК антибактеріального білка TFF3 у порожній і товстій кишиі і зменшити експресію антибактеріального білка RemIß i REG3y в порожній і товстій кишках. Результати забарвлення H\&E також показали, що МРX може полегшити патологічні пошкодження кишечника та внутрішніх органів миші, спричинені інфекцією, викликаною E. coli. Наведені вище результати показують, що MPX має хорошу бактерицидну активність проти E. coli у мищей, що є важливим для скринінгу ліків для клінічного лікування інфекції E. coli.

Ключові слова: антимікробний пептид MPX, Escherichia coli, мuшi. 